\title{
TARTU RADIOCARBON DATES VI
}

\author{
E ILVES \\ Institute of Zoology and Botany, Academy of Sciences, \\ Estonian SSR
}

The present list includes 35 dates of geologic samples analyzed at the Geobiochemical Laboratory of the Institute of Zoology and Botany, Academy of Sciences, Estonian SSR. Benzene synthesized from wood dating from $1850 \pm 10 \mathrm{yr}$ served as a reference standard. All radiocarbon dates have been calculated using $5568 \pm 30 \mathrm{yr}$ before AD 1950 as the half-life of ${ }^{14} \mathrm{C}$.

\section{Saviku Bog series}

A sec from an extensive bog system, Emajôe-Suursoo, located at the estuary of Emajôgi R, on the left bank of the river near its inflow into Lake Peipsi (Tartu Dist, Estonian SSR). Samples coll 1969 by E Ilves and A Sarv, pollen analyses by A Sarv.

TA-317. Saviku

$$
1620 \pm 50
$$

AD 330

Reed and sedge peat from depth 90 to $100 \mathrm{~cm}$. Boundary of Pollen Zones SAl and SA2.

TA-318. Saviku

$2490 \pm 50$

Reed peat from depth 150 to $160 \mathrm{~cm}$. Pollen Zone SAl.

TA-319. Saviku

Wood and reed from depth 230 to $240 \mathrm{~cm}$. Pollen Zone SAl.

TA-320. Saviku

$2850 \pm 70$

900 BC

Wood peat from depth 280 to $290 \mathrm{~cm}$. Boundary of Pollen Zones SB2 and SA1, Sub-Boreal and Atlantic contact.

TA-321. Saviku

$3130 \pm 60$

Wood and reed peat from depth 310 to $320 \mathrm{~cm}$. Culmination of spruce pollen. Pollen Zone SB2.

TA-322. Saviku

$3880 \pm 60$

930 BC

Wood and reed peat from depth 340 to $350 \mathrm{~cm}$. Boundary of Pollen Zones SB1 and SB2.

TA-323. Saviku

$$
4060 \pm 70
$$

2110 вC

Wood and reed peat from depth 380 to $390 \mathrm{~cm}$. Pollen Zone SB1. 
TA-425. Saviku

Wood and reed peat from depth 390 to $400 \mathrm{~cm}$. Boundary of Pollen Zones AT2 and SB1, Atlantic and Sub-Boreal contact.

TA-324. Saviku

$5690 \pm 70$

Reed peat from depth 480 to $490 \mathrm{~cm}$. Pollen Zone AT2. 3740 BC

\section{TA-325. Saviku}

$6900 \pm 70$

4950 BC

Peat-like sapropel with slight admixture of fine-grained sand and fragments of mollusk shells from depth 520 to $530 \mathrm{~cm}$. Empirical boundary of spruce pollen. End of Pollen Zone AT1.

TA-326. Saviku

$7110 \pm 70$

5160 BC

Peat-like sapropel with slight admixture of fine-grained sand and fragments of mollusk shells from depth 580 to $590 \mathrm{~cm}$. End of Boreal period.

TA-426. Saviku

$8090 \pm 70$

$6140 \mathrm{BC}$

Peat-like sapropel with admixture of fine-grained sand from depth 590 to $600 \mathrm{~cm}$. Sample contained mollusk shells (Valvata piscinalis [Müll] and Sphaerium corneum [ $\left.\mathrm{L}_{\mathrm{L}}\right]$ ). Determination of sp by J Vilbaste. Boreal maximum of pine pollen.

TA-327. Saviku

$$
9090 \pm 70
$$

7140 BC

Peat-like sapropel with admixture of fine-grained sand from depth 620 to $630 \mathrm{~cm}$. Sample contained mollusk shells (Planorbis carinatus [Müll], Sphaerium sp, Radix sp, Spirorbis spirorbis [L]). Determination by A Järvekülg. Pre-Boreal (PB) and Boreal (BO) contact.

\section{TA-328. Saviku}

$10,200 \pm 90$

Peat-like sapropel with admixture of fine-grained sand from depth 690 to $700 \mathrm{~cm}$, overlain immediately by DR3 and PB contacts.

\section{Haani series}

Submerged organogenic deposits from central part of $\mathrm{E}$ shore of Lake Vôrtsjärv, Estonian SSR. Samples coll 1970 by E Ilves and T Rinne.

\section{TA-233. Haani}

$470 \pm 60$

Peat from depth 87 to $90 \mathrm{~cm}$.

TA-234. Haani

Sapropel from depth 117 to $130 \mathrm{~cm}$.

$$
2510 \pm 60
$$

$560 \mathrm{BC}$ 


\section{Kurnovo Bog series}

Kurnovo Bog lies ca $7 \mathrm{~km} \mathrm{E}$ of town of Pechory, Pskov Region, RSFSR. Samples coll 1970 by E Ilves and A Sarv by hand from cleaned wall of quarry.

\section{TA-231. Kurnovo}

Peat from depth 75 to $80 \mathrm{~cm}$.

\section{TA-232. Kurnovo}

Peat from depth 95 to $98 \mathrm{~cm}$.

\section{Shalkar series}

Submerged wood remains near Lake Shalkar, Volodar Dist, Kokchetav Region, Kazakh SSR. Samples coll in 1969 and subm by A Shnitnikov, Inst Limnol, Acad Sci USSR.

\section{TA-383. Shalkar}

$380 \pm 50$

Submerged pine stump, age according to annual rings, $90 \mathrm{yr}$, discovered upside down in thick massif of fine sand on NE shore of lake. Depth, ca $1.2 \mathrm{~m}$.

\section{TA-381. Shalkar}

$470 \pm 50$

Submerged tree trunk from deposits of isolated lagoon on $\mathrm{N}$ shore of lake. Depth $2.4 \mathrm{~m}$ below surface of sand bar.

\section{TA-377. Shalkar}

$$
310 \pm 50
$$

Submerged pine stump, age according to annual rings, $26 \mathrm{yr}$, from lower submerged horizon in NE bay of lake.

\section{TA-376. Korzhun I}

Modern

Juniper trunk, age according to annual rings, $527 \mathrm{yr}$, from Dzhungar Alatau, basin of Koksu R, upper reaches of Korzhun R, $+2730 \mathrm{~m}$. Trunk lay on debris of left bank of Korzhun $\mathrm{R}$ valley, inside dense juniper shrubbery. No arboreal vegetation in area. Probable age, 400 to $500 \mathrm{yr}$. Sample coll and subm by A Shnitnikov.

\section{TA-430. Chatyrkyol I}

Algae from layer of submerged gyttja, 12 to $16 \mathrm{~cm}$ thick, among silty, well-interstratified sands of ancient deposits on left shore of Lake Chatyrkyol, Central Tien Shan, $+3530 \mathrm{~m}$. According to mode of occurrence, the sample age, 4000 or $5000 \mathrm{yr}$, was estimated. Sample coll by A Shnitnikov and E Maximov; subm by A Shnitnikov.

\section{Pesochnya Bog series}

Peat bog in Zheleznogorsk Dist, Kursk Region, RSFSR, 200m NE of village of Andreyjevskaya, S of Moscow-Kiev Hwy. Samples coll 1970 and 
subm by T Serebryannaya, Inst Geog, Acad Sci SSSR, who also did paleobotanic analyses.

\section{TA-357. Pesochnya}

Sedge peat from depth 120 to $125 \mathrm{~cm}$, at place of contact overlain by Carex and Bryales peat. Beginning of intensive forest clearance and plowing up of territories.

\section{TA-358. Pesochnya}

$1820 \pm 60$

Alder wood from horizon of wood and sedge peat at depth 195 to $205 \mathrm{~cm}$. Upper maximum of oak forest distribution.

\section{TA-352. Pesochnya}

$3830 \pm 60$

Reed and sedge peat from depth 305 to $310 \mathrm{~cm}$. Culmination of linden pollen.

\section{TA-359. Pesochnya}

$3720 \pm 60$

Basal reed and sedge peat (with slight admixture of fine-grained sand) from depth 310 to $315 \mathrm{~cm}$, above place of contact with reed and sapropel-like peat.

\section{Liniya Bog series}

Liniya peat bog lies in upper reaches of Gnilusha R, tributary of Oka R, Kromysk Dist, Orel Region, RSFSR, $300 \mathrm{~m}$ NE of village of Liniya, E of Moscow-Simferopol Hwy.

Light gray sapropels with scattered plant remains at base of sec. Higher in sec lie peat-like reed sapropel as well as various kinds of peat: Bryales with remains of wood and birch bark, Menyanthes-Phragmites and Menyanthes-Phragmites peat.

Peat bog covered with diluvial mantle, $120 \mathrm{~cm}$ thick. Absolute heights of mantle surface ca $220 \mathrm{~m}$ (Serebryannaya and Ilves, 1973). Samples coll and subm 1970 by T Serebryannaya, Inst Geog, Acad Sci USSR.

\section{TA-427. Liniya}

$1940 \pm 50$

Arbor-Menyanthes-Phragmites peat from depth 123 to $128 \mathrm{~cm}$, Upper maximum of oak forest distribution.

\section{TA-378. Liniya}

$$
2210 \pm 60
$$

Birch wood from horizon of Bryales peat $185 \mathrm{~cm}$ below surface, dating from period of oak forest distribution.

\section{TA-428. Liniya}

Reed peat from depth 229 to $232 \mathrm{~cm}$ at place of contact overlain by arbor-Menyanthes-Phragmites peat. Rational boundary of oak pollen. 
TA-429. Liniya

$2860 \pm 60$

Reed peat from depth 249 to $252 \mathrm{~cm}$. Replacement of principal forest-forming plant species, oak replaces linden.

\section{Retyazh series}

Samples from 2 secs in upper reaches of Retyazhi R, left tributary of Oka R, NW of village of Borisovka Kroysk Dist, Orel Region, RSFSR. River originates from confluence of 2 rather large streams cutting deep into winding valley. First 3 dates are from sec at base of left valley, $0.5 \mathrm{~km}$ from point of confluence of both sources of Retyazhi R; 4th date from sec lying on steep slope of right valley, $1 \mathrm{~km}$ from point of confluence of sources. Samples coll and subm 1970 by T Serebryannaya.

TA-373. Retyazh 6

$1250 \pm 60$

Peaty loam from depth 155 to $160 \mathrm{~cm}$, central part of bed.

\section{TA-374. Retyazh 6}

$2220 \pm 60$

Bryales and Carex peat from depth 220 to $225 \mathrm{~cm}$, upper part of bed.

\section{TA-375. Retyazh 6}

$3880 \pm 60$

Bryales and Carex peat from depth 290 to $295 \mathrm{~cm}$, central part of bed.

TA-360. Retyazh 8

$2410 \pm 60$

Carex peat from depth 170 to $175 \mathrm{~cm}$, upper half of bed.

$460 \mathrm{BC}$

\section{REFERENCES}

Serebryannaya, T and Ilves, E, 1972, First data on palynology and age of a watershed peat-bog in the central part of Central Russian heights near the town of Zheleznogorsk (in Russian). Acad Sci Estonian SSR Proc, Chem \& Geol ser, v 21, no. 2, p 161.

Russian heights (in Russian): Acad Sci SSSR Proc, Geog ser, no. 2, p 95-102. 